\title{
Literatura e sagrado Vozes boiando sobre o caos
}

\author{
Antônio Almeida Rodrigues da Silva ${ }^{1}$
}

\begin{abstract}
RESUMO
O objetivo do presente artigo, "Literatura e sagrado: vozes boiando sobre o caos", é estabelecer algumas aproximações entre literatura e sagrado. Para o diálogo, no âmbito da literatura, escolhi a obra Angústia, do romancista brasileiro, Graciliano Ramos. No campo da teologia, percebi no pensamento de Paul Tillich importantes elementos para uma possível conversa, sobretudo, no seu livro A coragem de ser, em que o teólogo destaca três tipos de angústias, a saber: angústia do destino e da morte, angústia da vacuidade e insignificação, angústia da culpa e condenação. Para o nosso propósito, darei ênfase à angústia do destino.
\end{abstract}

Palavras-chave: literatura, sagrado, diálogo

\section{LITERATURE AND SACRED: VOICES FLOATING ON CHAOS}

\begin{abstract}
The aim of this article, "Literature and Sacred: voices floating on chaos", is to establish some approximations between literature and the sacred. For the dialogue, within the scope of literature, I chose the work Anguish, by the Brazilian novelist, Graciliano Ramos. In the field of theology, I saw in Paul Tillich's thought important elements for a possible conversation, especially in his book The Courage to Be, in which the theologian highlights three types of anguish, namely, the anguish of fate and death, the anguish of emptiness and insignificance, anguish of guilt and condemnation. For our purpose, I will emphasize the anguish of fate.
\end{abstract}

Keywords: literature, sacred, dialogue

1 Doutorando em Literatura e Interculturalidade pela Universidade Estadual da Paraíba UEPB. Professor de Filosofia da arte - Universidade Federal do Amapá-UNIFAP. antonioalmeidars@hotmail.com 


\section{Considerações Iniciais...}

O presente trabalho objetiva discutir as relações entre literatura e sagrado. Para tanto, pretendemos estabelecer diálogos, pois, nesta direção, sempre aparecem coisas novas para além dos objetos estudados isoladamente. De acordo com Gilles Deleuze e Félix Guattari, a única questão quando se escreve, "é saber com que outra máquina a máquina literária pode estar ligada, e deve ser ligada, para funcionar" (2011, p.18). A literatura, portanto, é agenciamento. Entenda-se por agenciamento, ainda segundo Deleuze e Guattari, o crescimento das dimensões numa multiplicidade que muda necessariamente de natureza à medida que aumenta suas conexões. Assim sendo, tentarei sempre partir da "máquina" literária, no intuito de estabelecer pontes de comunicação com a "máquina" teológica e, em alguns momentos, fazer conexões, também, com a "máquina" filosófica. Nesta relação, certamente, haverá aproximações e distâncias, como é comum em qualquer conversa. No entanto, para o nosso objetivo, darei ênfase maior ao que as torna mais íntimas.

Para estabelecer esse possível diálogo, escolhi, no campo da literatura, a obra Angústia, do romancista brasileiro, Graciliano Ramos. O próprio título do romance já aponta para algo fundamental, a saber, o ser humano sempre terá diante de si o não-ser e, por isso, não consegue se livrar jamais das ambiguidades que permeiam nossa existência. Angústia desvela um indivíduo, Luís da Silva, narrador-personagem do romance, em constante conflito diante uma "realidade" marcada por contingências que, quase sempre, o "jogam" na mais terrificante angústia. Apesar do tema "angústia" permear toda a narrativa do romance, darei ênfase, neste artigo, à figura Luís da Silva, por razões, claro, de delimitação.

O interlocutor de Graciliano Ramos será o filósofo e teólogo alemão, Paul Tillich. Sua obra, como mencionado pelo próprio autor, está sempre na fronteira do pensamento, o que possibilita alguns diálogos com as mais variadas manifestações culturais, inclusive, para o nosso estudo, com a literatura. O tema da religião 
e da cultura ocupou um lugar central no pensamento de Tillich. Em cada criação cultural - um quadro, uma obra literária, um sistema, uma lei, um movimento político, por mais secular que possa parecer, se expressa sempre uma preocupação última, e é possível reconhecer o seu caráter teológico inconsciente.

Ora, se em cada criação cultural se expressa sempre uma preocupação última, Angústia, de Graciliano Ramos, por mais secular que pareça ser, aponta para algo incondicionado, porquanto as profundezas das angústias e dos dilemas humanos são desveladas de modo vivo. A história da arte, conforme Tillich, desde o começo do nosso século, tem que ser entendida à luz da tentativa desesperada do ser humano de voltar a si mesmo.

Sendo assim, quero pensar a relação entre literatura e sagrado a partir da complexidade do humano, longe de um campo definido e fechado de significações. É no cotidiano, longe de formulações metafísicas, que o entrelaçamento entre os dois saberes acontece. Literatura e teologia, portanto, "são vozes diferentes, cantando diversamente o mesmo tema. Isto constitui precisamente a 'polifonia', que desvenda o multifacetado da existência e a complexidade dos sofrimentos humanos" (BAKHTIN, 1997, p. 44).

Para estabelecer o diálogo entre Graciliano Ramos e Paul Tillich, seguirei os seguintes movimentos. No primeiro, apontarei algumas notas sobre Angústia, destacando, sem muita profundidade, fragmentos da crítica sobre o romance. Num segundo movimento, destacarei alguns elementos importantes da teologia da cultura elaborada por Tillich, dando ênfase às relações estabelecidas entre o sagrado e a cultura. Num terceiro e último movimento, tentarei estabelecer a conversa, entre os autores escolhidos, a partir de um tema comum: a angústia diante do destino.

Por fim, como assinala Eli Brandão da Silva (2001, p. 86), o texto escrito é o lugar, por excelência, onde as relações entre teologia e literatura se objetivam, onde seus textos se cruzam. Nosso interesse é, justamente, pensar esses cruzamentos, apontando para a importância do profícuo diálogo entre os dois saberes. 
Referimo-nos ao diálogo que se estabelece no interior de cada texto, onde vozes falam e polemizam entre si, produzindo um diálogo entre os muitos textos da cultura, contribuindo, deste modo, para a definição do sentido do texto. Noutras palavras, o texto deve ser entendido como o ponto de intersecção de muitos diálogos, cruzamento das vozes oriundas de práticas de linguagem socialmente diversificada (Ibid., p. 110-111).

\section{Breves notas sobre Angústia}

O espírito de Deus boiava sobre as águas

Graciliano Ramos

Analisando a obra de Graciliano Ramos percebi que a Crítica, como um todo, caminha em três direções: biográfica, psicológica e sociológica. Não tenho, por hora, interesse em percorrer esses caminhos, mas apresentar, parcialmente, uma visão geral do romance Angústia, publicado em 1936, utilizando-me, claro, de alguns comentadores que discutem as ambiguidades humanas presentes na obra. Esta contingência aponta, em Graciliano Ramos, Tillich, Sartre, Heidegger, entre outros, para uma angústia fundamental. Uma angústia diante do nada. Fica evidente, aqui, que meu principal recorte temático é o conceito de angústia. Por quê? Porque literatura e arte, como assinala Tillich (1976, p.30), "fazem da angústia um problema de suas criações, tanto no conteúdo como no estilo". A angústia toca o ser humano de forma tão profunda que, quase sempre, o leva a níveis da realidade que não seriam possíveis por outras vias.

Deleuze e Guattari afirmam que a arte, a ciência e a filosofia traçam planos sobre o caos. Eu acrescentaria, também, a teologia, não todas, claro, mas, em grande medida, a elaborada por Paul Tillich. Por se tratar de um pensamento de fronteira, a teologia tillichiana, sobretudo, sua teologia da cultura, não está preocupada em elaborações que reforçam doutrinas e dogmas de um gueto religioso, mas busca traçar planos, como veremos adiante, sobre o caos, nos seus mais diferentes diálogos com as mais variadas 
manifestações culturais. Deleuze e Guattari, referindo-se à arte, à ciência e à filosofia, agora acrescentada por mim, à teologia da cultura tillichiana: "não são como as religiões, que invocam dinastias de deuses, ou a epifania de um deus único, para pintar sobre o guarda-sol um firmamento" (1932, p. 260), entretanto, querem que rasguemos o firmamento e que mergulhemos no caos, na angústia, no desespero, nas possibilidades infinitas, longe das convenções sociais, religiosas etc.

Ora, é a partir do caos que quero pensar as intimidades entre literatura e sagrado. O poeta, o artista, como acrescentam Deleuze e Guattari (1992, p. 260), "abre uma fenda no guarda-sol, rasga até o firmamento, para fazer passar um pouco do caos livre e tempestuoso e enquadrar numa luz brusca, uma visão que aparece através da fenda". Caos livre e tempestuoso... É o que permeia de forma bem saliente toda a narrativa de Angústia. Caos livre e tempestuoso. Caos - "um espírito boiando". "Como seria?" "O espírito de Deus era levado sobre as águas” (RAMOS, 2009, p. 129). Literatura, caos... Sagrado, caos... Vozes boiando sobre o caos.

Para início de conversa, vamos estabelecer um diálogo amigável e rápido entre os críticos que conseguem perceber essa "realidade" caótica em Angústia. O intuito, aqui, é lançar alguns fragmentos de estudiosos para que o leitor tenha uma visão geral do romance.

O romance Angústia ocupa, de acordo com Hermenegildo Bastos (2008, p. 13), um lugar à parte na obra de Graciliano Ramos. Não por ser melhor ou pior do que os demais romances do autor, mas por radicalizar certos elementos já presentes nos romances anteriores. Tais elementos são de natureza temática, tais como, a alienação, a perquirição do eu, a solidão, o isolamento, a angústia, entre outros, mas também, elementos de técnica narrativa - a construção em abismo, o ritmo fragmentário, o monólogo interior, o solilóquio, a dissolução do espaço-tempo. Todos esses elementos estão presentes no romance e, vale salientar, não estão ligados apenas ao narrador-personagem. Vitória, só para citar um exemplo, é apresentada na narrativa como criada de Luís da Silva. Ela tem por hábito, quando recebe o seu salário, enterrar o 
dinheiro no fundo do quintal. Faltando poucos dias para Luís da Silva receber seu ordenado, sem dinheiro, e querendo participar de um evento na cidade, acaba violando a "cova" de Vitória. No entanto, o que ele não imaginava, era que fazendo isso, levaria o desespero a uma criatura que vivia sossegada. Seria o choque com o não-ser?

Toda a segurança daquela vida perdeu-se. A linha traçada do quarto à raiz da mangueira, uma linha curta que os passos trôpegos e vagarosos percorriam na escuridão, fora de repente cortada.

- Vá descansar, Vitória.

Conselho inútil. O céu de Vitória, miudinho, onde grilos e formigas moravam, tinha sido violado (RAMOS, 2009, p. 157).

Todos nós temos um céu miudinho, onde grilos e formigas moram sossegadas. E quando esse céu é violado? Temos, por certo, o contato cruel com os estilhaços da existência. Talvez, seja por isso que o ser humano lute com todas as suas forças para preservar suas verdades. Mundos de sentido. Céu "absoluto", mas totalmente frágil diante da violação de seus pressupostos. Já dizia Friedrich Nietzsche (2003, p.57).

No momento em que o homem que a transporta descobre uma coisa que o choca, dá meia volta, e diz consigo: 'enganaste-te! Onde é que estavas com a cabeça? Isso não pode ser verdade!' E, ao invés de examinar mais de perto e de ouvir com mais atenção, desata a fugir, como que intimidado da coisa diferente, e evita encontrar aquilo que o choca e procura esquecê-lo o mais depressa possível. Pois a sua lei interior diz: "não quero ver nada que contrarie a opinião corrente'.

$\mathrm{Na}$ relação com o mundo, essa possibilidade arrasta o ser humano à angústia. Angústia, como destaca Erwin Gimenez (2012, p. 212), parece emaranhar, de fato, os ziguezagues e entrecortes típicos de uma psique demolida sob os abalos da negatividade que se instala no cerne do indivíduo. Os excessos e insignificâncias, as descosturas e rebarbas profusas na superfície do texto impregnam a composição a fim de suscitar, num realismo crítico, os aspectos 
de tumulto e desenraizamento peculiares ao fracassado. Antonio Cândido, crítico importante da obra, chega a afirmar que "raras vezes encontraremos na nossa literatura estudo tão completo de frustração" (1992, p. 34). Para o crítico, Luís da Silva é um frustrado violento, cruel, irremediável, que traz em si reservas inesgotáveis de amargura e negação. Na mesma perspectiva, para Octavio Farias (1981), Graciliano Ramos traz, através a obra do ficcionista e, principalmente, do romancista, o mais impressionante e indiscutível dos testemunhos sobre a condição humana, o sentido do humano nas diversas imagens do homem a que dá cor, dimensão e vida.

A permanente situação crítica em que os personagens de Graciliano Ramos são lançados, quase sempre, diz algo sobre o conflito ser humano/mundo, no qual a tentativa de superação se faz a partir de uma interiorização, a partir de uma volta da consciência para dentro de si mesma. O sentimento de estranhamento do mundo, do seu não reconhecimento como lugar seguro de existência (MELO, 1995, p. 126). Outro crítico importante da obra, Carlos Coutinho, destaca que o que interessa a Graciliano Ramos é a narração do destino de mulheres e homens concretos, socialmente determinados, vivendo em uma realidade concreta. " $\mathrm{O}$ emprego de um tríplice tempo - o da narração do presente, o da recordação da infância e do passado e os devaneios subjetivos, o tempo subjetivo interior - introduz-nos em um fantástico universo de fragmentação e estilhaçamento" (2011, p. 174).

Angústia, portanto, retrata toda a miséria humana, mostrando a liberdade do ser humano frente às contingências da realidade exposta. Na obra, ficção e realidade se confundem, se pertencem, estão entrelaçadas. Não há uma fronteira muito bem definida sobre o que é ficção e o que é realidade. Luís da Silva, em um dos muitos momentos de angústia, diz: "as lembranças chegam misturadas com episódios agarrados aqui e ali, em romances. Dificilmente poderia distinguir a realidade da ficção" (RAMOS, 2009, p. 33). O que, afinal, é ficção? O que, afinal, é realidade? 
As breves notas sobre Angústia apontam para situações-limite de um ser humano marcado pelas adversidades da existência. $\mathrm{O}$ encontro perene com uma "realidade" movediça, capaz de escapar constantemente aos mais sublimes projetos, "leva" Luís da Silva, em certa medida, ao desespero, como perceberemos, adiante, na análise mais detida da obra.

\section{Religião, Cultura e Arte ${ }^{2}$}

A teologia de Paul Tillich elaborou-se, como destaca Etienne Higuet (1994, p. 50), num constante diálogo e confronto com os movimentos sociais, políticos, filosóficos, científicos e artísticos do século XX, no afinco de descobrir sua dimensão religiosa suprema, suas chances e seus desvios, suas exigências e seus apelos. Nos estudos tillichianos fica pulsante a relação estabelecida entre religião e cultura. O nível religioso está presente em toda produção humana nascida de preocupações intensas para com a questão do mistério e sentido da vida. Aqui, já temos um ponto para iniciarmos o possível diálogo entre literatura e teologia. Não há dúvida de que Angústia tem preocupações intensas em relação à existência. No romance, ficção e realidade se confundem num denso processo de tentativa de entendimento da realidade humana, com seus dramas, conflitos, necessidades, angústias, mortes, desejos, invejas, ódios, ciúmes..., tudo aquilo que permeia a vida concreta de mulheres e homens.

A teologia da cultura, elaborada por Tillich, consiste em penetrar nas mais diversas expressões culturais, à medida que estas estão aptas à revelação. Isto é, ela se encontra mais livre, porquanto está ligada ao movimento vivo da cultura - lugar em que os seres humanos se movem de forma mais ampla - estando aberta à diversidade de expressões culturais que surgem com a

2 Parte desse tópico, especificamente, foi publicada em outras edições da Revista Correlatio, a saber: Teologia da cultura: a essência do incondicionado nas multiformes expressões culturais (2006); Obras de arte e a irrupção do incondicionado (2008) e; O sagrado: exclusivo ou universal? Uma leitura a partir do pensamento teológico/filosófico de Paul Tillich (2010). 
história contínua dos humanos. A despeito disso, Tillich parece querer encontrar nesta relação de cultura e religião um saber acerca de ambas, de algum modo reconciliador. E é justamente nesta interface entre teologia e filosofia que ele concebe o que denominou "teologia da cultura", cujo conceito denota não meramente uma teologia aplicada à cultura, mas sim, uma teologia contextual. O caminho, consequentemente, para uma relação conciliadora tem de dar conta da natureza da cisão e mesmo do profundo abismo colocado entre cultura e religião na história do pensamento ocidental. É nesta perspectiva que ele elabora a sua celebre frase: "a religião é a substância da cultura e a cultura, a forma da religião" (TILLICH, 1974, p. 45). A cultura está relacionada à forma e a religião está relacionada ao conteúdo. Forma é todo objeto passível de investigação racional e crítica. Ela constitui o objeto imediato das diferentes atividades culturais autônomas. $\mathrm{O}$ conteúdo é visto mais de maneira espiritual. Ele não é alcançado por meio da visão objetiva racional, mas pela intuição. $O$ conteúdo é objeto da experiência, da participação existencial em sua realidade de envolvimento.

A religião, como preocupação última, é a substância que confere sentido à cultura e a cultura é a totalidade das formas em que se expressa a preocupação fundamental. A religião é a orientação do espírito para o sentido incondicionado. A cultura é a orientação do espírito em direção às formas condicionadas. Ambas se encontram em sua orientação para a unidade completada das formas do significado. Há uma convergência entre o sagrado e o secular. A preocupação última está presente mesmo em meio às inquietações triviais da vida das pessoas. "O secular é levado à união com o sagrado, uma união que na verdade é uma reunião, porque o sagrado e o secular se pertencem mutuamente" (TILLICH, 2005, p. 573-574). Ou seja, é impossível a existência do sagrado sem o secular. A religião precisa, necessariamente, dessa categoria para existir. Religião não pode se expressar, nem mesmo num silêncio significativo, sem a cultura, da qual ela assume todas as formas de expressão. Em cada uma das funções da criatividade cultural do ser humano palpita uma preocupação 
última. Quando religião e cultura se opõem, se destrói a unidade do significado, e se condena ao absurdo, ora na religião, ora na cultura (TILLICH, 1973, p. 48).

Salienta-se, aqui, a diferença, bem como a relação existente entre a religião estrita e religião ampla no pensamento tillichiano. Tal diferença é importante ser ressaltada para podermos entender melhor a relação existente entre religião e literatura. Religião significa ser preocupado ao extremo, fazendo a pergunta do "ser ou não-ser" com respeito ao significado da existência de uma pessoa, e ter símbolos nos quais esta pergunta é respondida. Este é o conceito maior e mais básico da concepção religiosa, ou seja, ser extremamente preocupado com o próprio ser de uma pessoa, com a própria pessoa, com o seu mundo, com relação ao seu significado, sua alienação e sua finitude (TILLICH, 1990, p. 2710). Ser religioso significa, então, perguntar com paixão pela significação da nossa existência e estar disposto a conhecer a resposta, mesmo que esta seja desagradável.

Tal ideia torna a religião universalmente humana, mas não há dúvida que diverge daquilo a que comumente se chama religião. "Não descreve a religião como crença na existência de deuses ou de Deus, e como conjunto de atividades e instituições destinadas a ligar cada pessoa a esses seres, pelo pensamento, pela devoção e pela obediência" (TILLICH, 1961, p. 73). A religião, em um sentido mais estreito, é identificada como crença na existência de um deus, ligada, neste caso, a atividades práticas e intelectuais que partem desta crença. São perceptíveis, nesse tipo de religião, declarações simbólicas sobre atividades do deus ou dos deuses cultuados. Ninguém pode negar que as religiões que apareceram na história obedecem a esse critério.

- Ah! Eu vi perfeitamente que o senhor é patriota (Julião Tavares)

Foi a conta (Luís da Silva)

- Quem o não é, meu amigo? Nesta hora trágica em que a sorte da nacionalidade está em jogo... (Luís da Silva) 
- Efetivamente, murmurei, as coisas andam pretas [...] (Luís da Silva)

- [...] Considero a religião um sustentáculo da ordem, uma necessidade social (Julião Tavares)

E divergi dele (RAMOS, 2009, p. 52-53).

Religião, como sustentáculo da ordem, apontará sempre para uma religião restrita. Religião ampla, viva, dinâmica, caótica..., está relacionada às ambiguidades e contingências da existência.

Em outra ocasião, após Marina procurar d. Albertina para fazer um aborto, Luís da Silva diz:

Pensando bem, d. Albertina atentara apenas contra Deus e contra a pátria. Se o cura da sé ouvisse um pecado tão grande no confessionário, daria ás duas mulheres penitência dura. Mas não haveria discurso, não haveria penitência, que elas não se julgavam culpadas e despediam-se de coração leve [...] A justiça e a religião não tomariam conhecimento do caso. E a família de seu Ramalho continuaria como estava, sem um escândalo para alimentar [...] Uma criatura que seria necessário vestir, calçar, nutrir e mandar à escola (Ibid., 2009, p. 213).

É esta constatação, segundo Tillich, que nos força a distinguir o sentido de religião viva, na dimensão da profundidade, de expressões particulares da preocupação fundamental com os símbolos e instituições duma religião concreta. A religião institucionalizada não tomaria conhecimento do caso e, por conseguinte, tudo continuaria como antes (Será?). O pecado tão grande vinculado a uma religião se contrapõe com a liberdade das duas mulheres que, na concepção de Luís da Silva, não se julgavam culpadas e, portanto, não haveria penitências. É o humano em contato com o não-ser; nas suas mais diversas possibilidades, que decide. No silêncio do caos, não existe o outro que me olha, mas apenas o eu, livre diante de uma situação dada.

O material da pergunta existencial é tomado da totalidade da experiência humana e de suas múltiplas formas de expressão. Refere-se ao passado e ao presente, à linguagem popular e à linguagem literária, à arte e à filosofia, à ciência e à psicologia [...] Enquanto o material da pergunta existencial é a própria expressão da condição humana, a forma da per- 
gunta é determinada pela totalidade do sistema e pelas respostas dadas nele (TILLICH, 2005, p. 310).

A percepção de que as artes invariavelmente se tornam espaços de manifestação de preocupação religiosa e mesmo de ligação com o transcendente, para Tillich, evoca uma das principais características do Incondicionado: o Incondicionado não tem sua ação limitada às esferas especificamente religiosas. Desta maneira, a criação artística tem por mérito a penetração na qualidade oculta das coisas.

A arte nos faz conscientes de algo que, de outro modo, não atingiríamos. Ela é, portanto, uma das formas pelas quais o ser humano é capaz de transcender sua finitude [...] Por meio dela, aquilo que está enraizado no fundamento do ser é descoberto. Esse é o grande milagre da arte (CALVANI, 1998, p. 80).

Tillich percebeu que, de algum modo, as ambiguidades da existência, presentes na produção cultural humana e na arte, encontram-se presentes na dimensão religiosa e teriam suas raízes, em última instância, no próprio incondicionado. Isto é, num nível profundo. A metáfora profundidade significa que o aspecto religioso aponta em direção ao que, na vida espiritual do ser humano, é último, infinito e incondicional. Essa preocupação última se manifesta em absolutamente todas as funções criativas do espírito humano. "Tudo o que determina o seu destino último, o infinito, o seu verdadeiro ser e a totalidade universal da qual faz parte, são motivos de preocupação última" (DREBES, 2005, p. 52). "O estigma da finitude", para Tillich, que aparece em todas as coisas, e o "choque" que se apodera da mente quando se encontra com a ameaça do não-ser revelam, por sua vez, o elemento abismal do fundamento do ser.

Em $A$ dimensão perdida da religião, Tillich descreve a atitude contemporânea relativa à religião, assinalando que devemos verificar, em primeiro lugar, sob que formas a consciência da condição do ser humano ocidental no nosso tempo se acha mais vivamente expressa. São elas, a arte, a literatura e, pelo menos em parte, 
a filosofia do nosso tempo. Para o teólogo, é tanto pelos temas como pelo estilo que estas criações revelam a luta apaixonada e muitas vezes trágica sobre o sentido da vida. Esta arte, esta literatura e esta filosofia não são religiosas no sentido estreito da palavra, mas põem o problema religioso mais radicalmente e mais profundamente do que as expressões contemporâneas de caráter propriamente religioso (TILLICH, 1961, p. 78). Neste sentido, Angústia põe o problema religioso, talvez, de modo muito mais profundo do que diversos segmentos religiosos da atualidade.

Obras de arte seculares em seu conteúdo, e esteticamente repulsivas, podem trazer em si um profundo significado religioso, visto que toda manifestação cultural expressa, não somente a si mesma, mas algo além dela própria, um posicionamento diante do Incondicionado. Esse posicionamento tem diversas facetas. Pode ser de acolhida e comunhão ou de indiferença ou rebeldia (CALVANI, 1998, p. 76).

\section{A angústia do Destino}

Movemo-nos como peças de um relógio cansado. As nossas rodas velhas, de dentes gastos, entrosam-se mal a outras rodas velhas, de dentes gastos. Angústia, Graciliano Ramos

Não há dúvida de que Angústia desvela, de forma crua, várias facetas da ambiguidade humana. Como já ficou enfatizado anteriormente, nosso recorte temático é o conceito de angústia. Faz-se necessário, portanto, definir tal conceito para, assim, seguirmos no possível diálogo, já anunciado, entre literatura e teologia. A angústia ${ }^{3}$, segundo Tillich (1976, p. 30) "é o estado no qual um

3 Para falar de angústia no pensamento de Tillich, seguirei as observações feitas por Carlos Calvani, quais sejam, Tillich, em $A$ coragem de ser, utilizou o termo anxiety (ansiedade) porque o mercado editorial norte-americano na época preferia traduzir Angst por Anxiety, tal como o fizeram Macquarrie e Robinson na primeira tradução de "Ser e Tempo" de Heidegger. Optamos, porém, por 
ser tem ciência de seu possível não-ser. O mesmo raciocínio, resumido, seria: angústia é a consciência existencial do não-ser. Nesta direção, a angústia estará sempre presente nas vivências dos seres humanos, pois o choque com o não-ser se mistura com o ser a cada passo dado.

É importante ressaltar, rapidamente, a diferença entre angústia e medo. $\mathrm{O}$ medo está relacionado a um objeto específico: tenho medo do escuro, tenho medo de altura, tenho medo da morte. A angústia, por outro lado, não tem objeto no qual o ser humano angustiado possa concentrar-se. "O único objeto é a própria ameaça, mas não a fonte da ameaça, porque a fonte da ameaça é o "nada" (Ibid., p. 31). A maneira que o ser humano tem de tomar consciência de sua liberdade é a angústia. A angústia, segundo Sartre, "é a consciência de ser seu próprio devir à maneira de não sê-lo" (SARTRE, 2008, p. 76). É porque estou infestado de nada que tanto o meu passado quanto meu futuro não oferecem qualquer porto seguro a partir do qual minhas decisões possam ser tomadas.

A armação de artilharia que precede um ataque pode provocar medo no soldado que sofre um bombardeio, mas a angústia começará quando ele tentar prever as ações contra o bombardeio e se perguntar se poderá 'suportar'. Igualmente, o convocado que se incorpora a seu regimento no início da guerra, pode, em certos casos, ter medo da morte; mas, mais comumente, ele tem 'medo de ter medo', ou seja, angustia-se diante de si mesmo (Ibid., p. 73).

Feitas essas considerações, doravante, poderemos seguir na nossa análise. A angústia que, em suas diferentes formas, está potencialmente presente em cada indivíduo, torna-se, como assinala Tillich, geral se as estruturas costumeiras de significação, poder, crença e ordem se desintegram.

acompanhar as observações de Ênio Müller, responsável pela revisão técnica da nova tradução da Teologia Sistemática publicada em 2005. Resultado de um projeto que envolveu tradutores e pesquisadores da área, a $5^{\mathrm{a}}$ edição revista da Teologia Sistemática no Brasil optou por "angústia". Afinal, nos textos escritos em alemão, Tillich sempre utiliza Angst, em semelhante acepção conceitual a Kierkegaard e Heidegger (CALVANI, 2017, p. 101). 
Levantei-me há cerca de trinta dias, mas julgo que ainda não me reestabeleci completamente. Das visões que me perseguiam naquelas noites compridas umas sombras permanecem, sombras que se misturam à realidade e me produzem calafrios (RAMOS, 2009, p. 7).

As primeiras palavras de Angústia, já anunciam os dramas que se seguiram por toda a narrativa. Luís da Silva, após um período de forte crise existencial, levanta-se, mas ainda sofre com as visões que insistem em persegui-lo. Luís da Silva, esse é um ponto importante que quero ressaltar, começa a narrar sua história após assassinar Julião Tavares. Não é de estranhar, portanto, toda a densidade dos acontecimentos narrados.

Pois bem, Luís da Silva começa a relacionar-se, intimamente, com sua vizinha, Marina. Ficam noivos e fazem planos para o casamento. Foi por esse tempo que Julião Tavares começou a entrar na existência de Luís da Silva. O encontro entre os dois aconteceu em um evento de arte no Instituto Histórico. Na saída, Julião Tavares, sem querer, deu um encontrão em Luís da Silva, mas imediatamente o segurou pelo braço o impedindo de cair. Julião Tavares era de família rica, Tavares e Cia, negociantes de secos e molhados, membros influentes da Associação Comercial. Para Luís da Silva, eram uns ratos. E Julião Tavares, literato e bacharel, devia, também, ser um rato, assim como o pai. Luís da Silva era funcionário público e, nas horas vagas, jornalista e escritor. Dias depois do encontro entre os dois no Instituto Histórico, Julião Tavares começou a frequentar a residência de Luís da Silva. "Ora foi uma vida assim cheia de ocupações cacetes que Julião Tavares veio perturbar. Atravancou-me o caminho, obrigou-me a paradas constantes, buliu-me com os nervos" (Ibid., p. 55).

Filho de uma puta. Esse artista privilegiado aperreou-me durante semanas, tirou-me o apetite. Na repartição, no cinema, no jornal, no café, perseguia-me a lembrança da voz antipática - Comecei a odiar Julião Tavares. Farejava-o, percebia-o de longe, só pelo modo de empurrar a porta e atravessar o corredor (Ibid., p. 59-60).

Os preparativos para o casamento estavam bem adiantados. Luís da Silva comprou um relógio-pulseira e um anel para presentear Mariana, quando, ao chegar perto da sua casa, recebe um 
choque tremendo. Julião Tavares pregava os olhos em Marina. O casamento não se concretiza e Julião Tavares começa a frequentar a casa de Marina, ficava lá horas, íntimo da família. "Aos domingos iam ao cinema, juntos, de braço dado, bancando marido e mulher - ele com ar bicudo e saciado, ela bem vestida como uma boneca e toda dengosa. Seda, veludo, peles caras, tanto ouro nas mãos e no pescoço que era uma vergonha" (Ibid., p. 116). Luís da Silva não tinha condições de dar nada disso para Marina e, em certo momento, até sonha em ganhar na loteria, pois, assim, daria a Marina, a vida de luxo que ela tanto almejava. O fragmento abaixo, um pouco longo, mostra, claramente, os sonhos de Luís da Silva em participar de uma classe social diferente.

O cego dos bilhetes da loteria passou entre as cadeiras, batendo com o cajado no chão, cantando o número. Se eu pegasse a sorte grande, Marina teria colchas bordadas à mão. Pobre de Marina. Precisava fazenda macia, pulseiras de ouro, penduricalhos.

- As cadeiras da minha casa eram bem ordinárias. No tijolo safado não havia tapete. Nem um quadro na parede. E o colchão, duro como pedra, faria escoriações no corpo de Marina. Contento-me com muito pouco, habituei-me cedo a dormir nas estradas, nos bancos dos jardins.

- 16.384, gemia o cego batendo com a bengala no cimento.

Ou seria outro número? Cem contos de réis, dinheiro bastante para a felicidade de Marina. Se eu possuísse aquilo, construiria um bangalô no alto do Farol, um bangalô com vistas para a lagoa. Sentar-me-ia ali, de volta da repartição, à tarde, como Tavares e Cia., dr. Gouveia e os outros, contaria histórias à minha mulher, olhando os coqueiros, as canoas dos pescadores.

$-16.384$.

Vestido de pijama, fumando, olharia lá de cima os telhados da cidade, os bondes pequeninos a rodar quase parados e sem rumor, os focos da iluminação pública, os coqueiros negros à noite. Uns quadros a óleo enfeitariam a minha sala. Marina dormiria num colchão de paina. E quando saltasse da cama, pisaria num tapete felpudo que lhe acariciaria os pés descalços.

-16.384 .

Revista Eletrônica Correlatio v. 16, n. 2 - Dezembro de 2017 
Um tapete fofo, sem dúvida. E a cama teria uma colcha bordada cobrindo o colchão de paina, uma colcha bordada em seis meses (Ibid., p. 88-89).

Depois de tantas angústias, Luís da Silva mata Julião Tavares.

Retirei a corda do bolso e em alguns saltos, silenciosos como os das onças de José Baía, estava ao pé de Julião Tavares. Tudo isto é absurdo, é incrível, mas realizou-se naturalmente. A corda enlaçou o pescoço do homem, e as minhas mãos apertadas afastaram-se. Houve uma luta rápida, um gorgolejo, braços a debater-se. Exatamente o que eu havia imaginado (Ibid., p. 237).

No entanto, ao matar Julião Tavares, Luís da Silva não se liberta das suas angústias, pelo contrário, parece haver uma intensificação delas. Julião Tavares continua bem presente no cotidiano de Luís da Silva, trazendo agonias muito maiores. Antes do assassinato, Luís da Silva acreditava que dando cabo de Julião Tavares seus dilemas diminuiriam. "A voz oleosa de Julião Tavares continuava a perseguir-me [...] Necessário dar cabo daquela voz. Se o homem se calasse, as minhas apoquentações diminuiriam" (Ibid., p. 115). Porém, para a sua surpresa, as apoquentações não diminuíram e, sim, aumentaram significativamente.

Vivo agitado, cheio de terrores, uma tremura nas mãos, que emagreceram. As mãos já não são minhas: são mãos de velho, fracas e inúteis. As escoriações das palmas cicatrizaram. Impossível trabalhar. Dão-me um ofício, um relatório, para datilografar, na repartição. Até dez linhas vou bem. Daí em diante a cara balofa de Julião Tavares aparece em cima do original, e os meus dedos encontram no teclado uma resistência mole de carne gorda (Ibid., p. 8).

A "cara balofa de Julião Tavares" continua lá, condenando Luís da Silva a conviver com a sua presença insuportável. Sombras que se misturam à realidade e produzem calafrios.

- Ainda que pudesse abolir o outro no momento presente, não poderia fazer com que o outro não houvesse sido. Melhor ainda: a abolição do outro, por ser vivida como triunfo da ira, pressupõe o reconhecimento explícito de que o outro existiu. Sendo assim, meu ser-Para-outro, deslizando ao passado, converte-se em uma dimensão irremediável de 
mim mesmo. É o que tenho-de-ser enquanto o havendo-sido. Portanto, não poderia livrar-me dele. Dir-se-á que, pelo menos, dele escapo pelo presente e dele escaparei pelo futuro: mas não. Aquele que, uma vez, foi Para-outro está contaminado em seu ser pelo resto de seus dias, mesmo que o outro tenha sido inteiramente suprimido: não deixará de captar sua dimensão de ser-Para-outro como uma possibilidade permanente de seu ser. Não poderá reconquistar aquilo que alienou; inclusive, perdeu toda esperança de agir sobre esta alienação e volvê-la a seu favor, já que o outro, destruído, levou para o túmulo a chave desta alienação. Aquilo que fui para o outro fica estabelecido pela morte do outro, e serei irremediavelmente no passado; também o serei, e da mesma maneira, no presente, caso persevere na atitude, nos projetos e no modo de vida que foram julgados pelo outro. A morte do outro constitui-me como objeto irremediável, exatamente como minha própria morte. Assim, em seu próprio surgimento, o triunfo da ira se transforma em fracasso. O ódio não permite sair do círculo vicioso. Representa simplesmente a última tentativa, a tentativa do desespero (SARTRE, 2008, p. 511).

Agora, é impossível Luís da Silva se livrar dessas sombras que o atormentam e, a partir de então, sua relação com o mundo e, também, com os outros indivíduos, passa, necessariamente, por essa alienação. Lugares que antes lhe davam prazer transformaram-se em lugares odiosos. "Essas sombras se arrastam com lentidão viscosa, misturando-se, formando um novelo confuso" (RAMOS, p. 9-10). O choque com o não-ser toma conta da sua existência e o faz ter uma visão da realidade totalmente negativa. $\mathrm{Na}$ busca pelo encontro de uma estabilidade emocional, Luís da Silva começa a buscar refúgio no passado.

Volto a ser criança, revejo a figura de meu avô, Trajano Pereira Cavalcante e Silva, que alcancei velhíssimo [...] Quando o carro para, essas sombras antigas desaparecem de supetão - e vejo coisas que não me excitam nenhum interesse [...] As recordações da minha infância precipitam-se (Ibid., p. 13-14).

Luís da Silva não consegue encontrar refúgio no passado, mas essa busca aparece com frequência em toda narrativa. "Penso em mestre Domingos, no velho Trajano, em meu pai. Não sei porque mexi com eles, tão remotos, diluídos em tantos anos de separação. Os defuntos antigos me importunam" (Ibid., p. 16). 
O passado não traz satisfação a Luís da Silva; suas lembranças sempre apontam para momentos decisivos e negativos em sua trajetória. É o pai, Camilo Pereira da Silva, que o afoga no poço de pedra quando Luís da Silva ainda não sabia nadar. É o espanto, depois da morte do pai, com a vida que iria suportar sozinho, fazendo-o sentir pena dele mesmo. "Eu estava ali como um bichinho abandonado, encolhido na prensa que apodrecia [...] Que ia ser de mim, solto no mundo?" (Ibid., p. 22). É na lembrança de que sempre brincava só e, por isso, cresceu besta e mofino. Mesmo diante desses fragmentos negativos, o passado parece ser melhor que o presente. "Entro no quarto, procuro um refúgio no passado. Mas não me posso esconder inteiramente nele. Não sou o que era naquele tempo. Falta-me tranquilidade, falta-me inocência, estou feito um molambo que a cidade puiu demais e sujou" (Ibid., p. 24).

Além disso, os fatos narrados por Luís da Silva apresentam-se de forma estranha. Os fatos não tem uma sequência lógica; suas lembranças são confusas e, por vezes, os pedaços da sua história chegam juntos. "Tudo empastado, confuso". "Em seguida os dois acontecimentos se distanciam e entre eles nascem outros acontecimentos que vão crescendo até me darem sofrível noção de realidade" (Ibid., p. 18-19). Nessa dinâmica, as feições das pessoas vão ganhando cor, tornando-se nítidas. As lembranças de sua história, como de qualquer outro indivíduo, apresentavam-se como indícios presentes em seu espírito, por isso, saem do "entorpecimento recordações que a imaginação completou” (Ibid., p. 18-19). Luís da Silva reconhece a impossibilidade de narrar uma história sem contradição.

Há nas minhas recordações estranhos hiatos. Fixam-se coisas insignificantes. Depois um esquecimento quase completo. As minhas ações surgem baralhadas e esmorecidas, como se fossem de outra pessoa. Penso nelas com indiferença. Certos atos aparecem inexplicáveis. Até as feições das pessoas e os lugares por onde transitei perdem a nitidez (Ibid., p. 130).

Luís da Silva vive essa ambiguidade de forma densa e, por conta disso, tenta negar uma realidade impossível de ser negada. 
Ela está lá, "olhando-o" como o gato em cima do muro, quando Luís da Silva "violou” a cova de Vitória, "mexia-me, e não podia desviar os olhos das duas tochas que me espiavam por cima do muro... Os olhos do gato cresciam, cresciam extraordinariamente, iluminavam o quintal todo" (Ibid., p. 152-153).

Diante da ambiguidade, Luís da Silva conclui, "quando a realidade me entra pelos olhos, meu pequeno mundo desaba" (Ibid., p. 96). Ele está diante da angústia do destino, isto é, está diante da mais cruel contingência.

Destino e morte, conforme Tillich (1976, p. 35), são os meios pelos quais nossa autoafirmação «ôntica" é ameaçada pelo não-ser. "Ôntica”, do grego on, "ser", significa aqui a autoafirmação básica de um ser por sua simples existência. A angústia do destino e da morte, para o pensador, é a mais básica, mais universal e, portanto, inescapável. Não há como negá-la e todas as tentativas acabam sendo frívolas. Tillich fala de dois tipos de ameaça contra a autoafirmação ôntica do ser humano: a ameaça absoluta da morte e, em termos relativos, a ameaça do destino. Apesar da angústia da morte e da angústia do destino estarem entrelaçadas, quero dar ênfase, aqui, sobretudo, à angústia do destino, na qual, acredito, Luís da Silva se move.

O termo "destino", no pensamento tillichiano, tem como característica seu caráter contingente, sua imprevisibilidade e a impossibilidade de mostrar sua significação e propósito. Pode-se descrever isto em termos da estrutura categórica de nossa experiência.

Pode-se mostrar a contingência de nosso ser temporal, o fato de existirmos neste, e não em outro período de tempo, iniciado num momento contingente, findando num momento contingente, preenchido com experiências que são contingentes [...] Pode-se mostrar a contingência de nosso ser espacial (nos encontrarmos neste e não em outro lugar, e a estranheza deste lugar a despeito de sua familiaridade); o caráter contingente de nós mesmos e o lugar do qual olhamos para nosso mundo; e o caráter contingente da realidade para a qual olhamos, isto é, nosso mundo. Ambos podiam ser diferentes: esta é sua contingência e isto produz a ansiedade referente à nossa existência espacial. Pode-se mostrar a contingência da interdependência causal da qual se é uma parte, dizendo respeito tanto 
ao passado como ao presente, às vicissitudes vindas de nosso mundo e às forças ocultas nas profundezas de nosso próprio eu (Ibid., p. 36-37).

O não ser, para Tillich, é onipresente e produz constantemente angústia. Ele está por trás de todas as nossas experiências e escolhas. Está por trás da insegurança e desabrigo de nossa existência social e individual. Está por trás dos ataques que sofre nossa potência de ser. $\mathrm{O}$ destino está ligado a tudo aquilo que é humano como tal. Estamos condenados à contingência porque nossa finitude é permeada de contradições, conflitos, tristezas, insegurança, angústias, liberdade.

Aqui, a questão do destino e de sua relação com a liberdade tem de ser levada em consideração, posto que a plena limitação da liberdade é explicitada quando percebemos a nossa falta de autonomia diante de várias situações da nossa existência. Por isso mesmo, a ideia de que o ser humano tem de lutar pela liberdade absoluta, tendo a autonomia para ser e fazer o que bem entender se choca com a ideia de destino. É impossível concebermos um conceito de liberdade sem relacioná-lo ao destino. Tillich assinala que "a liberdade, em polaridade com o destino, constitui o elemento estrutural que torna possível a existência, porque transcende a necessidade essencial do ser sem destruí-la" (TILLICH, 2005, 191).

A visão tillichiana de destino aponta para a situação em que o ser humano se encontra, isto é, a circunstância de se defrontar com o mundo, de pertencer ao mundo. Essa pertença não é a liberdade de uma função (a "vontade"), mas do ser humano; daquele ser que não é uma coisa, mas um eu completo. A vontade não pode ser considerada como a estrutura que representa plenamente o ser humano, porquanto ela não abarca a totalidade do eu. A liberdade do ser humano pressupõe que cada função que o constitui como um eu pessoal participa de sua liberdade (Ibid., p. 193). A liberdade, assim, é experimentada como deliberação, decisão e responsabilidade. 
1. Deliberação aponta para o ato de pesar (librare) argumentos e motivos. A pessoa que os pesa está acima dos motivos; enquanto os pesa, não se identifica com nenhum dos motivos, mas está livre de todos. A pessoa, através de seu centro pessoal, reage como um todo frente à luta desses motivos;

2. A decisão é a reação do ser humano. Uma decisão corta possibilidades, caso contrário, nenhum corte teria sido necessário. A pessoa que "corta" deve estar para além daquilo que ela exclui. É por isso que seu centro pessoal tem possibilidades, mas não é idêntico a nenhuma delas;

3. Responsabilidade designa a obrigação, da pessoa com liberdade, de responder se lhe perguntam sobre as suas decisões. A pessoa, nessa perspectiva, é responsável por suas escolhas. Seus atos não são determinados por algo fora dela nem por uma parte dela, mas por sua totalidade centrada no eu. Cada indivíduo é responsável por aquilo que aconteceu por ação do centro de seu eu, sede e órgão de sua liberdade.

Destino é, portanto,

Aquilo do qual surgem nossas decisões. É a base indefinidamente ampla de nosso eu centrado; é a concretude de nosso ser que torna nossas todas as nossas decisões [...] O destino não é um poder estranho que determina aquilo que me irá acontecer. É minha própria pessoa, tal como dada, formada pela natureza, pela história e por mim mesmo. Meu destino é a base de minha liberdade; minha liberdade participa na configuração de meu destino (Ibid., p. 193-194).

Tratando sobre a relação entre liberdade e destino, Hermenegildo Bastos (2011, p. 9) conclui que Luís da Silva sofre com o absurdo: a ausência de significado dos acontecimentos perturba-o, aniquila-o. A questão é a da incapacidade que ele tem de decidir sobre o seu próprio destino, sendo a narrativa entremeada por alusões, na maioria das vezes desconexas, ao destino do gênero humano. Será que Luís da Silva não tem capacidade de decidir sobre o seu próprio destino? 
Ora, se a angústia do destino está ligada à nossa contingência, é possível perceber, no caso de Luís da Silva, essa contingência em quatro níveis: fisionômica, social, ideológica e linguística, como veremos no quadro a seguir, sistematizado por Lúcia Carvalho (1983, p. 65).

\begin{tabular}{|c|c|c|}
\hline Série & Luís da Silva & Julião Tavares \\
\hline Fisionômica & $\begin{array}{l}\text { Magro, pálido, feio, boca mui- } \\
\text { to grande, nariz grosso, beiços } \\
\text { franzidos, testa enrugada. } \\
\text { Cabisbaixo, encolhido, curva- } \\
\text { do, desengonçado, roupa velha, } \\
\text { gravata enrolada, camisa estu- } \\
\text { fada, sapatos mal engraxados e } \\
\text { cobertos de poeira. }\end{array}$ & $\begin{array}{l}\text { Gordo, vermelho, perfumado, } \\
\text { risonho, falador. } \\
\text { Olhava em frente, andar emperti- } \\
\text { gado, espinhaço aprumado. } \\
\text { Bem vestido, smoking, grosso } \\
\text { rubi, peitilho duro, sapatos bri- } \\
\text { lhantes }\end{array}$ \\
\hline Social & $\begin{array}{l}\text { Níquel social, parafuso na má- } \\
\text { quina do Estado, valor miúdo. } \\
\text { Ocupação estúpida, funcio- } \\
\text { nário, quinhentos mil réis de } \\
\text { ordenado. } \\
\text { "Nunca estudei". } \\
\text { "Vida monótona, agarrada à } \\
\text { banca das nove horas ao meio- } \\
\text { dia e das duas às cinco". }\end{array}$ & $\begin{array}{l}\text { Negociante, família rica, Tavares } \\
\text { e Cia., importante. } \\
\text { Bacharel, literato e poeta, vestia } \\
\text { casaca, frequentava os bailes da } \\
\text { Associação Comercial. }\end{array}$ \\
\hline Ideológica & $\begin{array}{l}\text { Desconfia da revolução (mas a } \\
\text { deseja), desconfia da religião, } \\
\text { desconfia da justiça. }\end{array}$ & $\begin{array}{l}\text { Reacionário e católico; patrio- } \\
\text { tismo ufanista; "religião, um } \\
\text { sustentáculo da ordem, uma ne- } \\
\text { cessidade social". }\end{array}$ \\
\hline Linguística & $\begin{array}{l}\text { "As nossas conversas são } \\
\text { naturais, não temos papas na } \\
\text { língua". } \\
\text { "Minha linguagem é baixa, } \\
\text { acanhada. Âs vezes sapeco } \\
\text { palavrões obscenos". } \\
\text { "Ia escrever-lhe uma carta com } \\
\text { laços sagrados, felicidade con- } \\
\text { jugal. Infâmia. Só a ideia de } \\
\text { escrever isto me dava náuseas". } \\
\text { "As minhas frases eram con- } \\
\text { vencionais". }\end{array}$ & $\begin{array}{l}\text { "Linguagem arrevesada, muitos } \\
\text { adjetivos, pensamento nenhum". } \\
\text { "Linguagem pulha [...] o Brasil é } \\
\text { um mundo, os poetas alagoanos } \\
\text { uns poetas enormes..." } \\
\text { “... gritou discurso furioso e } \\
\text { patriótico. Citou coqueiros e as } \\
\text { praias, céu azul, os canais e ou- } \\
\text { tras preciosidades alagoanas. }\end{array}$ \\
\hline
\end{tabular}


Angústia, como ficou definido anteriormente, é o estado no qual um indivíduo tem ciência do seu possível não-ser. É a consciência existencial do não-ser. É o choque provocado diante de uma realidade que nos escapa. Nesse sentido, em Angústia temos algumas imagens interessantes que apontam para o estado e, sobretudo, a consciência de Luís da Silva em relação ao não-ser. Consciência aterradora. Uma força desconhecida que o joga sempre diante do caos, do desconhecido, do desordenado. E a sua angústia se intensifica diante da ameaça desse caos. "Qualquer coisa desagradável persegue-me sem se fixar claramente no meu espírito. Sinto-me aborrecido, aperreado" (RAMOS, 2009, p. 1516). Existe uma ameaça, não concreta, isso fica claro diante do fragmento acima, que o persegue.

É porque estou infestado de nada, que tanto o meu passado, quanto meu futuro, não oferecem qualquer porto seguro a partir do qual minhas decisões possam ser tomadas e, assim, Luís da Silva não consegue encontrar paz, nem no passado, já que suas lembranças sempre evocam algo de negativo. "Lá estava novamente entrando no passado, torcendo-me como parafuso" (Ibid., p. 153), diz Luís da Silva. Não consegue, também, ter tranquilidade no presente. Há, na "verdade", uma tentativa constante de se livrar desse presente. Se o passado e o presente não trazem tranquilidade, o futuro torna-se uma grande incógnita que, também, aponta para o choque com o não-ser. "O que será de mim para o futuro? [...] Caminho batendo nos transeuntes, enrolando palavras de desculpas, entrando no futuro como um parafuso" (Ibid., p. 147).

Após matar Julião Tavares, já em sua casa, tudo torna-se frágil: as paredes tornam-se inconsistentes, impressão de que a casa, a cidade caía lentamente, ruídos confusos eram ouvidos que o arrastavam para longe da realidade, as telhas e a garrafa de aguardente tornaram-se movediças. Seus cabelos arrepiavam-se, seus dentes tocavam castanhola e um frio agudo entrava na sua carne.

A réstia descia a parede, viajava em cima da cama, saltava no tijolo - e era por aí que se via que o tempo passava. Mas no tempo não havia horas. $\mathrm{O}$ relógio da sala de jantar tinha parado. Certamente fazia semanas que eu me estirava no colchão duro, longe de tudo. Eu escorregava nesses 
silêncios, boiava nesses silêncios como numa água pesada. Mergulhava neles, subia, descia ao fundo, voltava à superfície, tentava segurar-me a um galho. Estava um galho por cima de mim, e era-me impossível alcançá-lo. Ia mergulhar outra vez, mergulhar para sempre, fugir das bocas da treva que me queriam morder, dos braços da treva que me queriam agarrar (Ibid., p. 272-273).

Os criadores da arte moderna, conforme Tillich, têm sido capazes de ver a insignificação de nossa existência; participaram de seu desespero. Não só isso, mas, ao mesmo tempo, têm tido a coragem de expressá-lo e enfrentá-lo nas suas criações. Angústia mostra de forma expressiva o desespero de Luís da Silva em busca de tranquilidade. No desespero, o ser humano chega ao fim de suas possibilidades. A própria palavra, como destaca Tillich, significa "sem esperança", e expressa o sentimento diante de uma situação para a qual não existe "saída". "A dor do desespero é a agonia de sentir-se responsável pela perda do sentido da própria existência e de ser incapaz de recuperar esse sentido" (TILLICH, 2005, p. 368). O desespero de Luís da Silva, portanto, chega a uma situação extrema, isto é, não se pode ir além dela.

Angústia, de Graciliano Ramos, acertadamente, não é religiosa no sentido estreito e mais usual da palavra religião, porém, não existe dúvida, de que desvela a luta apaixonada e, em grande medida, trágica sobre o sentido da existência. Por isso, não simplificando a obra e, muito menos, a inserindo dentro de nomenclaturas, Angústia está impregnada de poder religioso porque mostra o humano diante da alienação e ambiguidade da vida. Angústia dialoga com o sagrado pela via do caos, da contingência, do choque com o não-ser. Como diria Tillich, o romance coloca a questão religiosa radicalmente, e tem o poder e a coragem para encarar a situação da qual emerge a questão da condição humana.

\section{Considerações Finais...}

Angústia é uma narrativa construída em círculo em torno da angústia existencial. São apresentados seres humanos marcados pelo choque com o não-ser. Logo no início do romance, Luís 
da Silva é perseguido por visões, sombras que se misturavam à realidade e traziam muita aflição ao narrador-personagem da obra. É importante reforçar, que a narrativa inicia após Luís da Silva se levantar, cerca de trinta dias, de uma profunda crise existencial. As últimas palavras do romance, por outro lado, mostram um Luís da Silva ainda prostrado numa cama. As sombras/visões permanecem lá, todas deitadas na cama com ele. Figuras como d. Albertina, o homem cabeludo, a mulher que trazia uma garrafa pendurada ao dedo por cordão, o vagabundo que dormia nos bancos dos jardins, o cego dos bilhetes, os cangaceiros, entre outros.

Tudo estava na parede, fazendo um zumbido de carapanãs, um burburinho que ia crescendo e se transformava em grande clamor [...] Um, dois, um, dois... A multidão que fervilhava na parede acompanhava José Baía e vinha deitar-se na minha cama [...] Milhares de figurinhas insignificantes. Eu era uma figurinha insignificante e mexia-me com cuidado para não molestar as outras (RAMOS, 2009, p. 284-285).

Como ficou dito, a preocupação última está relacionada com a preocupação humana em relação à existência. Tal concepção aponta para o conceito maior de religião, não preso aos dogmas e doutrinas de uma religião "particular". Neste ponto, encontramos possíveis diálogos entre literatura e sagrado. Em Angústia temos essa preocupação ao extremo com a realidade humana. Religião significa ser preocupado ao extremo, fazendo a pergunta do ser ou não-ser com respeito ao significado da existência de uma pessoa, sua alienação, sua finitude. Luís da Silva, entre outros personagens, pergunta com paixão pelo significado de sua existência. $\mathrm{O}$ sagrado se manifesta aí, no cotidiano cruel, na angústia do existir, na crise por afirmação; ideia que torna a religião universalmente humana. O sagrado se manifesta, longe do que o gueto religioso se acostumou a afirmar, mesmo nas situações mais "triviais" da existência humana. Não há dúvida, portanto, de que Angústia não é um romance religioso no sentido estreito da palavra, mas, utilizando-me da "fala" de Tillich, põe o problema religioso mais radicalmente e mais profundamente do que as expressões con-

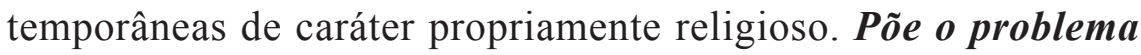
das ambiguidades e contingências da existência. 


\section{Referências}

BAKHTIN, Mikhail. Problemas da poética de Dostoiévski. Rio de Janeiro: Forense Universitária, 1997.

BASTOS, Hermenegildo. Apresentação. In: Graciliano Ramos e o mundo interior: o desvão imenso do espírito. Brasília: Editora UnB, 2008.

. Arte e liberdade em Angústia, de Graciliano Ramos. In: Miscelânea, Assis, v. 10, p. 9-22, jul.-dez. 2011.

CALVANI, Carlos Eduardo. Existirmos... a que será que se destina? Choque ontológico, angústia e coragem de ser na canção Cajuína. Correlatio. v. 16, n. 1 (2017), p. 99-113.

. Teologia e MPB. São Paulo: Loyola, 1998.

CANDIDO, Antonio. Ficção e confissão: ensaios sobre Graciliano Ramos. Rio de Janeiro: Ed.34, 1992.

CARVAlHO, Lúcia Helena. A ponta do novelo: uma interpretação de Angústia, de Graciliano Ramos. São Paulo: Ática, 1983.

COUTINHO, Carlos Nelson. Graciliano Ramos. In: Cultura e sociedade no Brasil: ensaios sobre ideias e formas. São Paulo: Expressão Popular, 2011.

DELEUZE, Gilles; GUATTARI, Félix. Rizoma. In: Mil Platôs: capitalismo e esquizofrenia 2. São Paulo: Editora 34, 2011.

. O que é a filosofia. Rio de Janeiro: Ed. 34, 1992.

DREBES, Haidi. A expressão da espiritualidade na obra pictórica de Frida Kahlo no horizonte da teologia da cultura de Paul Tillich. 2005. 173 F. Tese (Doutorado em Teologia) - Curso de Pós-graduação em Teologia, Escola Superior de Teologia, São Leopoldo, 2005.

FARIA, Octavio. Graciliano Ramos e o sentido do humano. In: Infância. Rio de Janeiro: Record, 1981.

GIMENEZ, Erwin. Mal sem mudança: notas iniciais sobre angústia. Estudos avançados. N. 26 (2012), p. 209-224.

HIGUET, Etienne. Atualidade da teologia da cultura de Paul Tillich, In: Revista eclesiástica brasileira, n. 213. Petrópolis, Instituto Teológico Franciscano, março, 1994.

MELO, Ana. "O desabrigo no mundo em Graciliano Ramos". In: Estudos. N. 5, nov 1995, p. 122-131.

NIETZSCHE. Friedrich. A gaia ciência. São Paulo: Martin Claret, 2003. 
RAMOS, Graciliano. Angústia. Rio, São Paulo: Record, 2009.

SARTRE, Jean-Paul. O ser e o nada: ensaio de ontologia fenomenológica. Petrópolis, RJ: Vozes, 2008.

SILVA, Antonio Almeida Rodrigues da. Obras de arte e a irrupção do incondicionado. Correlatio (www.metodista/br/correlatio), v. 7, n. 14 (dezembro de 2008).

. Teologia da cultura: a essência do incondicionado nas multiformes expressões culturais. Correlatio (www.metodista/br/correlatio) $)$ V. 5, n. 9 (maio de 2006).

. O sagrado: exclusivo ou universal? Uma leitura a partir do pensamento teológico/filosófico de Paul Tillich. Correlatio (www.metodista/br/ correlatio). v. 9, n. 18 (dezembro de 2010).

SILVA, Eli Brandão da. O nascimento de Jesus-Severino no auto de natal pernambucano como revelação poético-teológica da esperança: Hermenêutica transtexto-discursiva na ponte entre teologia e literatura. 2001. $291 \mathrm{f}$. Tese (Doutorado em Ciências da Religião) - Universidade Metodista de São Paulo, São Paulo, 2001.

TILLICH, Paul. A coragem de ser. Rio de Janeiro: Paz e Terra, 1976.

. A dimensão perdida da religião. In: Aventuras do espírito. Coordenado por Richard Thruelsen e John Kobler. Rio de Janeiro: Editora Fundo de cultura, 1961.

Religião, 1992.

A era protestante. Trad. Jaci Maraschin. São Paulo: Ciências da

. Existentialist aspects of modern art (1956). In: Main works/Hauptwerke. Berlin/New York: De Gruyter/Evangelisches Verlagswerk, 1990. V. 2, p. 273. Aurora, 1973.

Filosofía de la religión. Buenos Aires: Asociación Editorial La

. Teología de la cultura y otros ensayos. Buenos Aires: Amorrortu editores, 1974.

. Teologia sistemática. 5a ed. São Leopoldo: Sinodal, 2005. 